\title{
Umbilical Endometriosis: A New Dermoscopic Pattern
}

\author{
Jorge Juan Vega-Castillo ${ }^{1}$, Soledad Saenz-Guirado ${ }^{1}$, Maria Luisa Vega-Castillo², \\ Ricardo Ruiz-Villaverde ${ }^{1}$
}

1 Dermatology Department, Hospital Universitario San Cecilio, Granada, Spain

2 Ophtalmology Department, Hospital de Alta Resolución de Écija, Spain

Key words: endometriosis, pattern, dermoscopy

Citation: Vega-Castillo JJ, Saenz-Guirado S, Vega-Castillo M, Ruiz-Villaverde R. Umbilical endometriosis: a new dermoscopic pattern. Dermatol Pract Concept. 2022;12(1):e2022023. DOI: https://doi.org/10.5826/dpc.1201a23

Accepted: June 10, 2021; Published: January 2022

Copyright: $\odot 2022$ Vega-Castillo et al. This is an open-access article distributed under the terms of the Creative Commons Attribution License BY-NC-4.0, which permits unrestricted noncommercial use, distribution, and reproduction in any medium, provided the original authors and source are credited.

Funding: None.

Competing interests: None.

Authorship: All authors have contributed significantly to this publication.

Corresponding author: Ricardo Ruiz-Villaverde, Unidad de Dermatología. Hospital Universitario San Cecilio, Granada, Spain. E-mail: ismenios2005@gmail.com

\section{Introduction}

Endometriosis is defined as the growth of ectopic endometrial tissue outside the uterine cavity. Extra pelvic endometriosis occurs in $12 \%$ of women, and umbilical endometriosis, a rare presentation of extra pelvic endometriosis, occurs in $0.5 \%-1 \%$ of reported cases. Umbilical endometriosis is also known as Villar nodule as Villar first described the condition in 1886. Cutaneous endometriosis tends to settle on scars from surgical procedures (abdominal or pelvic surgery) such as hysterectomy, caesarean section, laparoscopy, or episiotomy. From a clinical point of view, it is necessary to establish a differential diagnosis with amelanotic melanoma, basal cell carcinoma, Sister Mary Joseph nodule, or pyogenic granuloma.

\section{Case Presentation}

A 45-year-old woman attended our dermatologic outpatient clinic complaining of a 4-months history of a solitary painless umbilical nodule. The bluish-green colored lesion had not appeared on a previous scar. Any recent bleeding episode was ruled out. A complete medical history revealed longterm dysmenorrhea as the only relevant clinical finding. On dermoscopy, a central white reticular pattern on a violet background was observed (Figure 1A). No vascular structures, points, globules, or structures suggestive of a melanocytic lesion were observed. Histopathological examination was consistent with cutaneous endometriosis (Figure 1B). Complementary tests, including abdominal-pelvic CT and determination of cancer antigen 125 offered results within normal ranges.

\section{Conclusions}

There are few dermoscopic descriptions in the literature of cutaneous endometriosis [1,2]. The main dermoscopic findings and histopathological correlation are reflected in Table 1. There appears to be a difference in patterns depending on the phase of the hormonal cycle, as well as the depth of the lesion, histological subtype and phototype of the patient. 


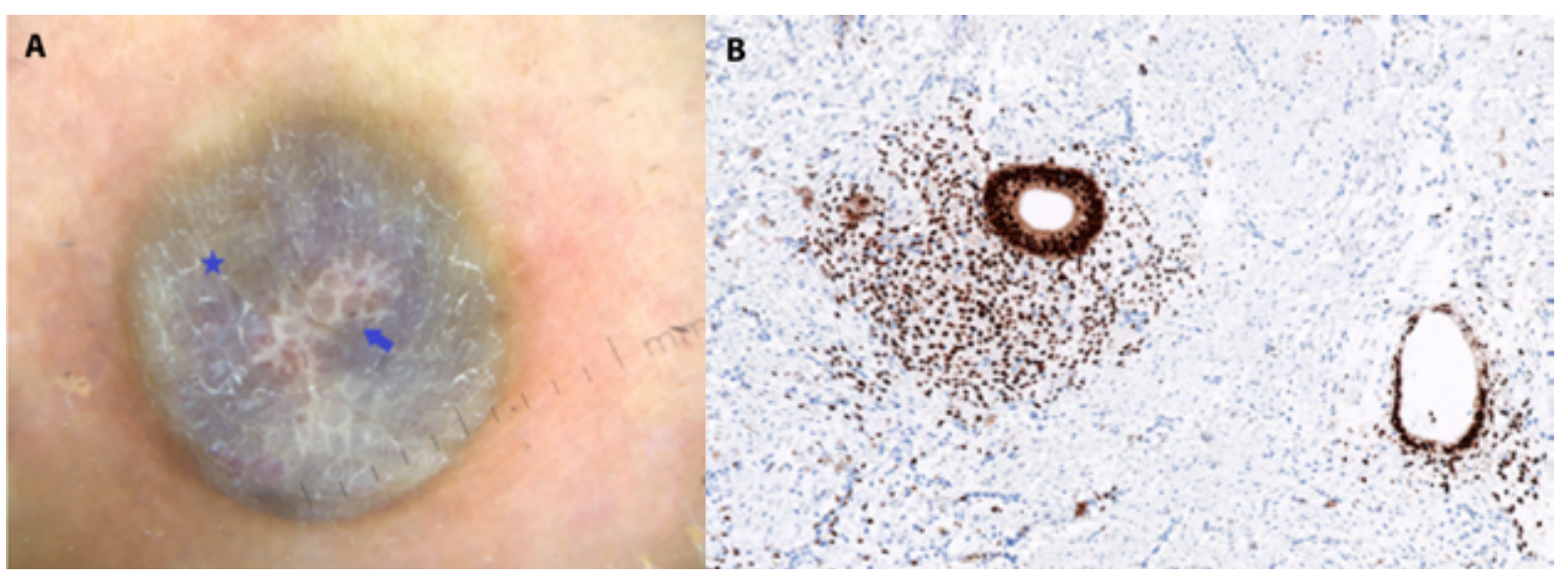

Figure 1. (A) Polarized dermoscopy shows central white reticular pattern (blue arrow) on a violet background (blue star) (DermLite DL4, $\times 10)$. (B) Histopathology shows positivity for progesterone-receptor markers in endometrial glands and stroma (immunohistochemistry: anti-progesterone receptor antibodies; original magnification, $\times 100$ ).

Table 1. Dermoscopic Descriptions of Umbilical Endometriosis

\begin{tabular}{|c|c|c|c|c|}
\hline Authors & Dermatoscope Model & Dermoscopic Features & Interpretation & Polarized Mode \\
\hline $\begin{array}{l}\text { De Giorgi, } \\
2003 \text { [3] }\end{array}$ & Heine-10 & $\begin{array}{l}\text { Homogeneous reddish } \\
\text { pigmentation, regularly } \\
\text { distributed, gradually fading to } \\
\text { the periphery Small red globular } \\
\text { structures (red atolls) }\end{array}$ & $\begin{array}{l}\text { Multiple irregular } \\
\text { glands with } \\
\text { erythrocytes in a } \\
\text { myxoid vascular } \\
\text { stroma }\end{array}$ & Non-polarized \\
\hline $\begin{array}{l}\text { Jerez-Jaime, } \\
2013 \text { [4] }\end{array}$ & DermLite II Pro HR & $\begin{array}{l}\text { Homogeneous reddish } \\
\text { localized pigmentation, with } \\
\text { no differentiated structures } \\
\text { Amorphous brown area with } \\
\text { normal skin network }\end{array}$ & $\begin{array}{l}\text { Myxoid vascular } \\
\text { stroma }\end{array}$ & $\begin{array}{l}\text { Polarized light } \\
\text { dermoscopy }\end{array}$ \\
\hline $\begin{array}{l}\text { Costa, } \\
2014[5]\end{array}$ & DermLite DL3, & $\begin{array}{l}\text { Polypoid projections of } \\
\text { erythematous violaceous color, } \\
\text { area with dark brown globules } \\
\text { and area of active bleeding (mid } \\
\text { follicular phase) Increased in both } \\
\text { characteristics (luteal phase) }\end{array}$ & $\begin{array}{l}\text { Endometrial atrophy } \\
\text { Hemoglobin } \\
\text { degradation after } \\
\text { bleeding period, } \\
\text { corresponding to } \\
\text { hemosiderin deposits }\end{array}$ & $\begin{array}{l}\text { Polarized light } \\
\text { dermoscopy }\end{array}$ \\
\hline $\begin{array}{l}\text { Bonné, } \\
2020 \text { [2] }\end{array}$ & DermLite DL4 & $\begin{array}{l}\text { Umbilical endometriosis (polypoid } \\
\text { structure) with drainage openings }\end{array}$ & $\begin{array}{l}\text { Multiple irregular } \\
\text { glands with } \\
\text { erythrocytes and } \\
\text { drainage openings }\end{array}$ & $\begin{array}{l}\text { Polarized light } \\
\text { dermoscopy }\end{array}$ \\
\hline $\begin{array}{l}\text { Sandoval, } \\
2021[6]\end{array}$ & Unknown & $\begin{array}{l}\text { Pink homogeneous lesion with a } \\
\text { focal bluish blotch/clod }\end{array}$ & $\begin{array}{l}\text { Hemosiderin } \\
\text { deposits }\end{array}$ & $\begin{array}{l}\text { Polarized light } \\
\text { dermoscopy }\end{array}$ \\
\hline
\end{tabular}

White reticular pattern (negative pigment network) is due to elongated rete ridges and is characteristic of melanoma. Nevertheless, it has also been observed in Spitz/Reed nevi. The diffuse area of bluish color is likely related to hemosiderin deposits, unlike the referred deposits observed in other cases reported as small focused globules.

Histopathological examination remains the diagnostic gold standard for endometriosis. It is considered mandatory in ruling out a neoplastic condition, as more than $60 \%$ of umbilical tumors are malignant. The description of new dermoscopic patterns and their histological correlations can be helpful in the diagnosis of this entity.
Informed consent: Informed consent for publication of clinical details and clinical images was obtained from the patient.

\section{References}

1. Boesgaard-Kjer D, Boesgaard-Kjer D, Kjer JJ. Primary umbilical endometriosis (PUE). Eur J Obstet Gynecol Reprod Biol. 2017;209:44-45. 44-45. DOI: 10.1016/j.ejogrb.2016.05.030. PMID: 27374811.

2. Bonné E, Daxhelet M, Simon P, Del Marmol V, Suppa M. The peculiar dermoscopic features of primary umbilical endometriosis. J Eur Acad Dermatol Venereol. 2020;34(10):e589-e591. DOI: 10.1111/jdv.16455. PMID: 32277548. 
3. De Giorgi V, Massi D, Mannone F, Stante M, Carli P. Cutaneous endometriosis: non-invasive analysis by epiluminescence microscopy. Clin Exp Dermatol. 2003;28(3):315-7. DOI: 10.1046/j.1365-2230.2003.01194.x. PMID: 12780722.

4. Jaime TJ, Jaime TJ, Ormiga P, Leal F, Nogueira OM, Rodrigues N. Umbilical endometriosis: report of a case and its dermoscopic features. An Bras Dermatol. 2013;88(1):121-4. DOI: 10.1590/ s0365-05962013000100019. PMID: 23539017; PMCID: PMC3699952.
5. Costa IM, Gomes CM, Morais OO, Costa MC, Abraham LS, Argenziano G. Cutaneous endometriosis: dermoscopic findings related to phases of the female hormonal cycle. Int J Dermatol. 2014;53:e130-2. DOI: 10.1111/j.1365-4632.2012.05854.x. PMID: 23621541

6. Sandoval M, Meza-Romero R, Peñailillo A, Villaseca MÁ, Navarrete-Dechent C. Dermoscopy findings of umbilical endometriosis. Australas J Dermatol. 2021;62(1):e139-e141. DOI: 10.1111/ajd.13437. PMID: 32909620. 